\title{
Revisiting Modernism and the Myth of the Descent to the Underworld
}

\author{
The Fin-de-siècle Hell of Indifference \\ and Fragmentation in Charles Palliser's The Sensationist
}

\begin{abstract}
This paper approaches Charles Palliser's The Sensationist (1991) in the light of one of the myths most frequently found in modernist art and literature: the descent to the underworld. It argues that The Sensationist also resorts to the myth of the descent to hell, but it does so in a way that the final result can be regarded as an altered version of what Evans Lansing Smith has called the sequence "rape-revelation." Likewise, the novel's form is analyzed - with its alternation between homodiegetic and heterodiegetic narration - as illustrating an evolution which has left the once coherent ego further and further behind, moving from wholeness to alienation and then to fragmentation; that is to say, from unity to disintegration. The analysis concludes by briefly connecting the overall picture that emerges from The Sensationist with what Gilles Lipovetsky refers to as Narcissistic culture in the age of the void, which coincides with the cultural paradigm Palliser fictionally recreates in his second novel.
\end{abstract}

Charles Palliser's The Sensationist was published in 1991. To the reading public, this was Palliser's second novel but, as the author himself has explained, he actually wrote it during a short break from work on The Quincunx (1989). ${ }^{1}$ After years of re-

1. The novel certainly did not pass unnoticed. Ballantine bought the American rights and a few months later Penguin purchased the UK paperback rights and published it in 1990. Palliser's novel was chosen by Waterstone's as Book of the Month and it was short-listed for The Saltire New Author, the Yorkshire Post First Novel, and the Hawthornden Prize. In April 1991 the American Academy and Institute of Arts and Letters awarded Palliser the Sue Kaufman Prize for First Edition for The Quincunx. Translation rights were sold in six languages and The Quincunx appeared at the top of many best-sellers lists in the UK, the USA, Canada, Holland and Belgium. In 1993 Viking reprinted a new hardback edition including an "Author's Afterword" to the novel.

The AnaChronisT 13 (2007-2008): 181-201 ISSN 1219-2589 
search into the history and literature of nineteenth-century England in order to produce a highly complex novel whose contents and style should be evocative of Victorian fiction, Palliser simply wanted to write something different from all that, a story for which he needed no research at all, something short, with a straightforward plot and a contemporary setting. He would try to portray life in a universe in which immediate sensations were paramount. The intensity of experience linked with sex, alcohol and drugs would come to the front through a character who did not ponder on his actions, who did not consider the moral implications of his behaviour. This was the genesis of The Sensationist, which Palliser has described as an "antidote," a reaction to all the process of writing The Quincunx. ${ }^{2}$

Despite all differences between The Quincunx and The Sensationist, the two novels have in common the fact that they engage the reader in a complex intertextual game, and so, where The Quincunx abounds in Victorian echoes, The Sensationist reverberates with allusions to modernist and early postmodernist writers, from D. H. Lawrence, Virginia Woolf and William Faulkner to John Fowles and the early Martin Amis. Aiming at intensity and economy, Palliser finally produced something similar to a long poem in the guise of a novel. Language is highly metaphorical, oblique, elliptical. Action is reduced to a minimum and the emphasis falls on moods and sensations suggested through images, sounds, smells. Sentences are short, syntax is fragmented, and the text resembles stream of consciousness.

Just as the novel's style is reminiscent of that in much modernist fiction, so the novel's contents can be rewardingly interpreted in the light of one of the myths most frequently found in the context of modernist art and literature: the myth of the descent to the underworld. In what follows, I will approach Palliser's novel from the perspective provided by such a myth and I will resort for that purpose to Evans Lansing Smith's study of the descent to the underworld and its treatment in modernist literature. The way in which The Sensationist fits, but ultimately departs from the scheme provided by Smith will throw light on Palliser's re-writing - from a postmodernist perspective - of what we find in much modernist fiction, which nonetheless functions as the novel's main intertext.

As Smith points out, the descent to the underworld is the single most important myth for modernist authors. ${ }^{3}$ Nearly all the major writers from 1895 to 1945 use it as

2. Gilles Menegaldo, "Entretien avec Charles Palliser," La Licorne 44 (1998) 267-83, pp. 278-279.

3. Evans Lansing Smith, Rape and Revelation: The Descent to the Underworld in Modernism (Lanham, Maryland: University Press of America, 1990), p. 1. 
a means of conferring on their works that shape and significance which T. S. Eliot thought to be the consequence of the mythical method or, what is the same, of myth's ability to make "the modern world possible for art." 4 Indeed, the modernists themselves developed their own terminology to express an apocalyptic relationship between the descent into Hades and the revelation of the fundamental patterns shaping life and art (archetypes, in Jungian terminology). In modernist literature, more specifically, the discovery of those mythic patterns seems to require a previous crippling of the traditional, stable ego, a deathlike movement out of life and towards a renewed awareness. The self in crisis is thus healed by an illuminating experience in the works of W. B. Yeats, T. S. Eliot, Ezra Pound, Thomas Mann, James Joyce, Joseph Conrad and D. H. Lawrence, among many others. 5

This conception of the underworld as a granary or repository of the only forms (archetypes) capable of making art and life meaningful at a time of flux constitutes one of the four chambers of the underworld. The other three have to do with the respective views of it as an ancestral crypt, as a sacred site of initiatory transformation (temenos) and as inferno. ${ }^{6}$ As the crypt of the ancestral dead, the underworld contains those great poets of the tradition whose voices haunt the works of Eliot, Joyce, and Pound, to cite a few. As temenos, the underworld becomes a vessel of initiation. D. H. Lawrence has most fully exploited this dimension of Hades. His sexual scenes constitute a celebration of the erotic descent into darkness, a physical abduction from which his characters return (ideally) as resurrected ones. And, as inferno, the metaphor of the underworld is used in modernism to explore the dark side of psyche and history. This is the case with Conrad's Heart of Darkness (1902), Lawrence's The Plumed Serpent (1926), Mann's Death in Venice (1912) and Doctor Faustus (1947), etc. Later in the century, Malcolm Lowry, Herman Broch, and Thomas Pynchon would also concur in their visions of life during World War II as a catastrophic inferno inhabited by demons of political and sexual lust. In the same line, there is, as well, a slightly less cruel view of the world, like the one which inspired Eliot. His

4. T. S. Eliot, “Ulysses, Order and Myth,” Dial 75 (1923) 480-83, p. 483.

5 . Not only the works but also the lives of many modernists feature a crisis that seems to have led to the revelation of the archetypal forms of imagination. Jung himself also experienced such a crisis, which he saw as his personal descent into Hades, and it was in the course of it that the myths at the core of his future work were revealed. For a discussion of the relationship between the underworld and the archetypal categories of the imagination, see his 1935 "A Psychological Commentary on The Tibetan Book of the Dead," in Psychology and Religion: West and East (New York: Pantheon Books, 1958).

6. Smith, p. 3 
"hollow men" lack the grandeur of real devils, they wander across the moral wasteland of modern life like spectres locked eternally in the hell of their own ennui.

What I would like to argue, in the light of Smith's contention, is that The Sensationist features the various aspects of the underworld distinguished by the abovementioned author and that it does so in such a way that the final result can be approached as a parody (in Linda Hutcheon's sense ${ }^{7}$ ) of what Smith has called the sequence "rape-revelation." The term "rape" here must be understood in relation to Persephone's myth, as her abduction to Hades begins, literally, with a rape. In the context of modernist literature, the "raped" figure is a victim in a more general sense: it is the alienated character, bizarre, peculiar, sick, in a word, wounded. That is the case of Eliot's Prufrock, the characters in Joyce's Dubliners (1914) and the husband in D. H. Lawrence's Lady Chatterley's Lover (1932). Yet it is important to remember that the rape initiates the revelation in the myth, symbolised by the transformation of Persephone from struggling victim to bride of Hades. In literature, revelation is expressed in the form of archetypal images, mythical structures, epiphanic moments characters experience, etc.

In a wide range of modernist works, then, things fall apart in order to fall together again. But this is not the case with The Sensationist. Like Alasdair Gray's Lanark (1981) and Iain Banks' The Bridge (1986), Palliser's revision of the myth as dealt with in modernist literature features the process of breakdown but not the moment of breakthrough. The novel abounds in images of the underworld and the protagonist's descent into hell is presented, in typically modernist fashion, as instability, alienation and threatened unity. When David, the novel's main character, finds what could have been the agent of his transformation, the artificer of his enlightenment, he proves incapable of responding adequately to the situation. As a consequence, the centre around which he could have arranged his life fails to hold, and things are not very different in as far as his job, his flat, and the city as a whole are concerned.

Myths themselves might not literally serve as a source for the writer, or at least a conscious source, but they serve as powerful underlying structures capturing human experience: myths contain a culture's most ingrained expressions of the experience of life. Thus, if as John B. Vickery points out, "literary plots, characters, themes and images are basically complications and displacements of similar elements in myths

7. Linda Hutcheon, A Theory of Parody: The Teaching of Twentieth-Century Art Forms (London: Methuen, 1985). 
and folktales," 8 by delving into these "complications and displacements" one may reach some conclusions about a culture's deepest driving forces. Shape-shifting personae and plots are a common feature of myths and legends (one only has to think of Ovid's Metamorphoses), but they also have a literary progeny in which it is the myths themselves that appear in different guises. Accordingly, when one focuses on Palliser's second novel and its connection with Persephone's legend, one cannot but conclude that the most significant transformation is that affecting the pattern suggested by the myth itself; and just as the metamorphoses within the myth have a meaning that goes beyond the story it tells, so the change affecting the myth's rationale (its rape-revelation dynamics) has significant implications when it comes to interpreting the novel and the worldview that emerges from it.

One of the most significant features of The Sensationist is that the traditional constraints of time, place and name are virtually eliminated alongside with fundamental information about the main character, his job, the people he meets, etc. No wonder, then, that the novel's plot can be summarised in a few lines. From what we are told, the protagonist arrives in a northern city (whose name is never mentioned) at the end of the summer. He has accepted a new job there, which will offer him the possibility of developing a risky but challenging scheme in the financial market world but which remains, from beginning to end, a sheer mystery. Long hours in front of the computer, together with parties, sex, alcohol and, eventually, drugs, fill David's (no surname) agenda. On meeting Lucy, things start to change, to make sense, but when further commitment is required of him, he answers by turning a blind eye to the symptoms of an emotional and mental breakdown (hers) that is under way. Eventually, both his relationship with Lucy and his job collapse and he leaves the city less than a year after his arrival, at the beginning of the summer fair.

The way in which David relates to other people, on the one hand, and the link that exists between him and the city, on the other, constitute the two points of reference (at the story level) against which the alienation and progressive fragmentation of the protagonist's self are to be measured. Through similes, metaphors, personifications and other rhetorical devices, the city is depicted as an autonomous mechanism whose streets and gutters resemble the entrails of a living being and whose inhabitants seem to be less alive than the city itself. Surrounded by a land-

8. John B. Vickery, ed., Myth and Literature (Lincoln: University of Nebraska Press, 1966), p. 8 o. 
scape "too remote from his own countryside of farms and villages" (94)9 and unable, even, to understand the locals' northern dialect, David's feeling of alienation becomes acute. Detached from everything and everybody, his only link with the world around him becomes reduced to sensorial impressions. Special attention is paid to sights, noises, smells, but there is nothing deeper than that. No wonder, then, that the only way in which he relates to others should be purely physical. As David sees bodies, and not human beings in all their complexity, sex becomes the logical outcome.

In as far as sex is concerned, David's creation of a self through a promiscuous pursuit of ever-new lovers - reminiscent of Jinny in Virginia Woolf's The Waves (1931) and Nicholas Urfe in John Fowles' The Magus $(1965,1977)$ - already involves discontinuity and fragmentation. His quick affairs are invariably of the kind in which no emotional attachment is involved, a fact that makes of sex the easiest relationship. Wary of further responsibilities, David has no interest whatsoever in his lovers' lives. On the contrary, "intimacy with strangers," we are told, "was the most exciting thing he knew" (38).

As if to fill the protagonist's lack of beliefs, sex is increasingly regarded by him in terms of ritual. Love-making becomes a form of worship, while his potential partners - women he sees on buses and in trains especially - are likened (in words that bring to mind the Marquis de Sade's blasphemous sexual ceremonies) to parishioners "waiting for a religious service to begin" (50). The climax, in turn, amounts to a privileged, sacred moment of clarity in which all meaning is held by the purposeful motions of two bodies. David's search for lovers actually hides a search for meaning, which appears to be invariably condemned to failure. As happens with D. H. Lawrence's male characters, the kind of fulfilment that sex provides is never permanent. On the contrary, its evanescent quality makes the meaninglessness that once and again follows it even harder to accept: "But then the consequence: nothing resolved" (50).

The other way in which David is presented to the reader turns the city into a metaphor, an image suggestive of the protagonist's solipsism and gradual dissolution. G. M. Hyde has argued that modernist literature was born in the city and with Baudelaire - especially with his discovery that crowds mean loneliness and that the

9. All parenthesised references are to this edition: Charles Palliser, The Sensationist (London: Cape, 1991). 
terms "multitude" and "solitude" are interchangeable. ${ }^{10}$ It was perhaps T. S. Eliot, above all others, who best pressed urban multitudes into service as specimens of degeneracy and sterility. The Waste Land (1922) is about sterility, especially where it is about burning sexual desire (in the section based on the Buddha's Fire Sermon). Likewise, sex and sterility get fused in The Sensationist and the city becomes the means through which the protagonist's relational problems are expressed. Like everything else in the novel, the city is described from David's point of view and, accordingly, it changes with him. The characteristically modernist dominance of viewpoint over material accounts, then, for a picture of the city which depends entirely on the way in which the main character looks at it.

From the very beginning, the city disturbs David with "its sense of mystery withheld, of strangeness made familiar" (1). Its grey atmosphere finds a prolongation in its inhabitants who look "bedraggled, beaten, sullen" (4). Human beings become microcosms which reproduce at a smaller scale the macrocosm where they are enclosed. Accordingly, both the city and the locals appear hollow at the core. The city is literally so: an elaborate network of wires and pipes runs under the ground, roads have been dug and re-dug, "like the scarred veins of an addict" (19) and, deeper, there are the ancient sewers, connected by fetid canals. The decadent, depressing aspect of the surface (derelict buildings, long hours of darkness, endless winters, the soft but steady rain) has its counterpart underground, in the wastes that circulate out of sight through the city's vacuities.

While the city becomes "a slowly evolving organism," its inhabitants are no more than artefacts "plugged" into it (19), neither living nor dead, "eating, heating, excreting" (18). Or, is it the city that does so? The statement remains teasingly ambiguous: it may refer to the people, but it could do as well to the "humanised" city, whose tunnels are compared to monstrous urinals (4) and whose buildings move like "loose teeth in a rotten gum" (24). Like the city, David is a "surface" enclosing a dark and empty core; like the buildings, he seems to be helpless against the forces which threaten to reduce him to a heap of fragments. Significantly, the atmosphere that surrounds David in this first part of the novel can be defined as hellish, depicted, quite often, with reference to motifs associated with the journey or descent into Hades.

From the day of his arrival, David seems to move in a world of shadows and unclear images. Lying in the darkness of his room, he gets engrossed watching the

10. G. M. Hyde, "The Poetry of the City," in Modernism 1890-1930, ed. Malcolm Bradbury and James McFarlane (1976; London: Penguin, 1994), p. 337. 
transformations of the shadows made by the light that comes through the window. The city's weather conditions condemn him to move permanently "through darkness and rain" (11) and the clouds become a "misted glass" (35) which covers the sun, "the darkness lifting that late, returning so early" (40). The overcast sky and the slums, the humped old buildings which have become ghosts of what they used to be, make him feel enclosed, trapped among spectral figures. Sometimes even human bodies seem to blur around the protagonist. At parties, for instance, the revolting lights turn people into shapes perceived among wine bottles or reflected on glasses and windowpanes, all life frozen in the dizzying flash of the strobes. On such occasions, drugs and alcohol distort even more David's perception of external reality. Under their effect, he becomes "strange to himself" (21), hypersensitive to a body that, more and more often as the story goes on, seems to lead a life of its own. The painful darkness, the smell, the heat, which simultaneously attract and hurt him, further round up the depiction of each party as a nightmarish (underworld) scenario where, interestingly, every smile betrays "a soul in pain" (26).

Another view of hell is provided by the description of David's workplace: a suite of windowless offices which make him feel as if he were "hundreds of feet underground" (15). This is a realm of silence and a realm of death as well. Linking these two concepts, James Hillman points out that the speech of the dead usually appears as a whisper and that many are the authors who, following the Roman poets, refer to the dead as mute. ${ }^{11}$ Thus, in Eliot's The Hollow Men (1925), those who have crossed over to the kingdom of death see formless shapes and colourless shades who whisper like the wind and huddle together like rats in a cellar. Likewise, the only sounds to be heard in the building where David spends most of the day are the hissing of the ventilation and the humming of the machines, as the carpeted floors in offices and corridors absorb not only louder noises but also human voices. In addition, the pale neon light accounts for the lifeless, colourless atmosphere of the place and makes David's colleagues look "hung-over" (7). The cafeteria, low and dark, has the same kind of fluorescent lighting under which people crowd as if living dead, lacking in spiritual energy, shuffling forwards in a way that is strongly reminiscent of Eliot's hollow men crossing London Bridge.

On David's first visit to what would be his flat, and even before he makes up his mind to rent it, he is already put off by the design on the coloured glass of the door: an ill-drawn St George, wrapped in the scaly coils of a serpent (an underworld crea-

11. James Hillman, The Dream and the Underworld (New York: Harper and Row, 1979), p. 206. 
ture, often associated, in Christian symbology, with the Devil), and holding a sword which appears to thrust disconcertingly at his own body. The apartment is said to look empty, though it has quite a lot of furniture, and dark, even when the lights are on. In addition, the floors slope to the back of the building, a fact which generates in the protagonist a permanent fear of falling. As soon as he moves in, strange cracks start to awake him in the middle of the night, and yet, he manages once and again to get over the panic of feeling the bed move under his body by convincing himself that "all was normal" (24). The cracks, though, leave their scar on his mind and just as scars remain on the flesh, so the terror of losing touch will never abandon him. In fact, it seems as if it had always been with him, since the moment he learned at school that the earth was spinning and became "terrified of being flung off if he stopped concentrating" (62). Being flung off and falling down amount to the same thing here. Both are symptoms of the protagonist's mental unsteadiness and sense of groundlessness.

If David's malady links him with a wide range of modernist characters, such as Virginia Woolf's Rhoda in The Waves (1931) or the consul in Malcolm Lowry's Under the Volcano (1947), his growing obsession with a hidden underworld as well as with the instability of the earth's surface can equally be related to the way in which modernist literature echoed the discoveries made by modern science in the early decades of the century, when Einstein published his theories of relativity and, along with Niels Bohr, laid the foundations of quantum mechanics. The notion that there is an underlying structure, a world within the world of the atom, captured the imagination of artists at once. ${ }^{12}$ In fact, developments in science came to a dramatic climax with the shift from mechanicist to quantum-relativistic physics (a shift coterminous with modernism: say, from 1905, the year of Einstein's first publication on relativity theory, to the 1930s, when Bohr, Einstein and Enrico Fermi worked out the details of the New Physics).

The de-substantiation of the solid world described by the New Physics logically leads to the postulate that physical entities which seemed to be separate are actually linked, implicitly unified. This notion applies to Palliser's novel in as far as boundaries between characters, and between them and the city are concerned. Clear-cut distinctions disappear and individuals are reduced to "a mass of people" (8, emphasis added), a "blotch of noisy, frightened humanity" (9, emphasis added). Yet the screw is given a further turn when the city's inhabitants are presented as a mere counterpart of their environment. In strange and complex ways, then, the part is in

12. Cf. Jacob Bronowsky, The Ascent of Man (Boston: Little Brown, 1973), p. 330. 
the whole and the whole is in the part, even if it is David's mind that effects such a connection. As Fritjof Capra puts it, those new theories suggested that consciousness may well be an essential aspect of the universe and that "the observed patterns of matter are reflections of patterns of mind."13 David's view of things and events appears in this light as a reflection of his own psyche, a fact which highlights the importance of a recurrent element throughout the narrative: the protagonist's dreams and visions. Moreover, these products of David's unconscious can be regarded as a further link with the metaphor of the underworld. According to Smith, dreams and visions have often been used in modernism to explore the dark side of human psyche ${ }^{14}$ and, in the same line, James Hillman begins his book on the dream and the underworld with a discussion of Freud's description of the subconscious as a "psychological underworld" inhabited by figures "fixed in their repetitions, unredeemable" and eternally suffering. ${ }^{15}$

Analysing The Waste Land (1922) or, more specifically, some of the motifs relevant to the descent to the underworld in the poem, Smith mentions, among others, that of a man swimming to the bottom of the sea and a dream vision of a person a long time dead from a Poe story about the collective presence of all the dead. ${ }^{16}$ Likewise, on his very first night in the city, David dreams of a school-friend of his "whom he now saw drowning in front of him, crying out speechlessly, his white legs descending an invisible stair-way" (3). Once again, silence appears as the speech of the dead, while the way of dying recalls Eliot's death by water as well as the last stage in the Heraclitean descensus ad infernos: from air to earth to the waters below. Yet if the dead can be said to be present in the novel, such presence is achieved mainly through David's visions of Paul, which come to haunt the protagonist from the very moment he learns that his colleague has died of a heart-attack (probably due to the fact that he was "hitting too much" at the time). He first sees him after one of his quarrels with Lucy. Walking about the city, looking for her smile, her face, her beauty, what he finds, by contrast, is Paul's figure moving ahead of him in the street (81). Later on (121) he gets a close-up of his shadowed face, grinning at him and then laughing mischievously among other people (other dead?). He sees him asleep and awake as the nightmare of waking life gets mixed with his worst dreams.

13. Fritjof Capra, The Turning Point: Science, Society and the Rising Culture (New York: Bantam, 1982), p. 93.

14. Smith, p. 4.

15. Hillman, pp. 18, 22.

16. Smith, p. 28. 
David's constant fear of falling and his obsession with decay and rottenness (the wastes at the port, the city's stench, its demolished houses, or the fetid canals) also reach their climax in his dreams. If during the day he feels as if he could fall down at any moment, he actually does so in his nightmares $(49,89)$, which constitute perhaps the most vivid, hair-raising picture of the underworld's darkest chamber. But, as has been pointed out, the myth of the descent to the underworld appears at different levels in The Sensationist. The protagonist's view of the city and its inhabitants, already commented on, should be regarded as a less cruel, though not less terrifying rendering of an inferno crowded with lost and sickened (not really evil) souls. Thus dream and waking life combine in order to create David's private hell, a hell which, nonetheless, offers him a chance of transformation and renewal.

When the protagonist first sees Lucy in an art gallery, she, her dark hair, her blue eyes, come to obsess him: "It seemed to him that she was the centre around which the things that had long puzzled him would form a pattern" (46). Likewise, when he learns her name he thinks that she could have had no other: Lucy, the one who brings light to the darkness in which he is immersed. Thus, his memories of her lure David with a promise of order and coherence with which to overcome the randomness and unintelligibility of human life in general and of his own life, in particular. This is, in fact, the promise of the temenos, the sacred site of initiatory transformation that Evans Lansing Smith points out as one of the chambers of the underworld.

One day, looking out of the window, he sees Lucy again in the park opposite his flat. If, at the moment of being overcome by Hades, Persephone was playing with the nymphs, picking flowers in a meadow, David approaches Lucy in a park, where she is playing with her child Sally "running up and down on the grass, picking up and scattering handfuls of wet leaves" (53). The rain, the leaves on the ground, David's surprise at seeing snow on the roof of a car, which, he concludes, must have come from the mountains (as if the winter were still far), together with the fact that, from what we know, the protagonist arrived at the city at the end of the summer and has not been there long, these are all details that may help the reader place the scene in time and, at least, venture that it must occur in autumn, the same season when Persephone is said to have been taken away by Hades. In the myth, Persephone's mother, Demeter, succeeds only partially in recovering her daughter since, as Hades' bride, she must spend half the year with him: from autumn to spring. It is also in spring that David's relationship with Lucy starts breaking down and definitely ends shortly before David leaves the city, at the beginning of the summer. What happens, then, till they reach this point? 
As has been explained, the fact that events, people and places are invariably presented to the reader from David's point of view brings to the fore the modernist contention of the impossibility to keep perceiver and world apart. Thus, the transformation that David notices around him as Lucy enters his life draws into sharper focus the notion that reality, far from being fixed, depends on who sees it and how s/he looks at it. "Seeing," in a word, gives way to what Wittgenstein called "seeing-as."

In the second part of the Philosophical Investigations (Philosophische Untersuchungen, published posthumously in 1953), and within the context of a broad consideration of the problem of meaning, Wittgenstein calls attention to a certain distinctive visual experience: the abrupt change in perceptual content that can occur through the dawning of a new aspect or the identification of a new principle of coherence. Thus we can see an arrangement of lines as convex and then suddenly as concave; Jastrow's well-known design may appear now as a duck, now as a rabbit; etc. What is distinctive about such cases, observes Wittgenstein, is that the object remains unchanged while the visual experience may alter radically: "I see that it has not changed and yet I see it differently." It is "quite as if the object had altered before my eyes," as if it "had ended by becoming this or that."17

This train of thought is perfectly applicable to the protagonist's altered view both of his life and of the world, which appears as the logical outcome of his having found a point of reference around which everything seems to cohere. The city now seems to him "a Florence turned inside out" (63). Likewise, a pattern emerges out of the maze of streets that criss-cross it, a pattern formed by the lines between his flat and Lucy's place, the gallery where she works, the school attended by her daughter Sally, the restaurants where they meet, etc. For the first time, he thinks of his future, his career, as something he can make, and the conviction that the path he will follow has not been marked out for him, but depends entirely on his own decisions, makes him feel alive and free. This sudden thrust towards coherence also affects David's fragmented self, which now acquires a new unity. Such an epiphany of self-identity, which reaches its climax when making love with Lucy, is described in words that, as Susana Onega has pointed out, ${ }^{18}$ echo the trance-like experiences of D. H. Lawrence's heroes on similar occasions: "Until then, he believed, he'd never made love. Never known the findings of self in the unawareness of self, the celebration of something

17. Ludwig Wittgenstein, Philosophical Investigations, trans. G. E. M. Anscombe (New York: Macmillan, 1971), pp. 193, 195, 206.

18. Susana Onega, "Charles Palliser," Post-war Literatures in English 19 (1993) 1-12, p. 8. 
beyond the pleasure of receiving - even of giving - delight through the intimacy of two strangers' bodies" (67).

The protagonist's discovery of new patterns of meaning can be related to what Smith refers to as a transformation from the naturalistic perspective of ego to the psychic perspective of soul. ${ }^{19}$ As the descent to the underworld produces an intensification of psyche, Persephone's abduction precipitates the revelation of the already-mentioned "eidola of Hades," that is, of "the ideational forms that shape and govern life." 20 Thus, David manages to experience order and meaning, and yet, he will prove incapable of responding adequately to them.

The more the relationship progresses, the deeper David's fear of compromise grows, a fear which prevents him from actually becoming part of Lucy's life. As Onega explains, Lucy possesses - like Lily in The Magus (1966), and also like Lydia Lenski in The Rainbow (1915) from whom both heroines can be said to descend that combination of remoteness and mysteriousness which is the mark of the Lawrentian "true" woman. ${ }^{21}$ It is this disquieting ambivalence that, on the whole, links Lucy even further with the mythical Persephone. In as far as the latter is concerned, she is, on the one hand, the delicate and innocent youth at play in the sunny fields, a creature of beauty and light frequently associated with flowers (which she was picking at the moment of her bereavement). On the other hand, there is Persephone Queen of the Underworld, a creature of darkness, tenebrous and unrevealed. This same double-sidedness can be applied to Lucy. Her eyes, brilliant blue, the clearest David has ever seen, are shadowed by thick dark lashes. Her pale skin contrasts with the dark hair, which "smelt of coal as if its blackness derived from that subterranean mineral, and shone like coal when it caught the light" (65). She is often referred to as "a child" (59), "a small child" (66), "a little girl" (67), whose face becomes "even younger" while making love, her slender body "rapt in its devotedness," "nun-like" (65). Yet her smile is "secretive" (63), and sometimes turns into a mischievous grin (63). Just as Persephone's life in the upper world remains unknown to Hades, so "Lucy's life apart from himself [David] was mysterious" (62). But even if she appears to be free and have a life of her own, David seeing her only when she lets him do so, there seems to be something in her relationship with the protagonist that makes her feel entrapped: "Let me go, let me go" (71), she cries out in her sleep.

19. Smith, p. 14.

20. Smith, pp. 13, 18.

21. Onega, p. 7 . 
So is Lucy, fragile, innocent, playful, childish, but also mysterious, absent and, sometimes, even cruel and cold. ${ }^{22}$ As to David, his attitude towards her only manages to widen the rift in her personality. Far from trying to make her one and whole, David is ready to relate to the first Lucy while he keeps the second at bay, thus precipitating her eventual breakdown. Her previous lovers, her child's father, Sally, her career as a painter, all this remains confined to a darker sphere in Lucy's life which David is unwilling to explore or, rather, afraid to do so, because that would create a closer tie between them, a bond he is wary of. No wonder, then, that whenever the idea of forming a family with Lucy and Sally comes to his mind, he immediately dismisses it as "a temptation ... to which he would not capitulate" (113). Significantly, by the time this happens, David has missed the one chance to renew himself, to make a start, not at Lucy's cost ("feeding off her energy," 67), but with her.

In a scene that recalls the trip to Mount Parnassus by Nicholas and Alison in John Fowles' The Magus, Lucy feels compelled to swim in the frozen waters of the loch while David gets annoyed with her and, unlike Nick in the aforementioned novel, chooses to remain on the shore, blind to the regenerative ritual symbology of bathing. ${ }^{23}$ David's failure to perceive the potentially redeeming qualities of water turns Lucy's bath into the opposite of what it could have been: from (re-)birth to a figurative death by water. In this way, the picture of the underworld as temenos (place of initiation) recedes only to be succeeded by the initial view of it as inferno.

It is immediately after this episode that Lucy starts showing definite signs of mental imbalance, and it is also then that David first feels the desire to humiliate and hurt her while making love, thus feeding Lucy's dangerous masochism (a quality she shares with other archetypal virgin/whores like Henrietta, in The Quincunx, and also Sarah Woodruff in Fowles' The French Lieutenant's Woman). Afraid of her for him, rather than afraid for her, David's instinct for safety begins to operate until he remorselessly stops seeing the by now deranged Lucy. Far from being the solid and stable centre for which David is eager to take her, Lucy is, rather, the basis of an (unconscious) strategy through which the protagonist tries, as everybody else in the city does, to "ward off the terror and postpone the night" (37).

As their relationship breaks off, the nightmare of David's daily life comes back to him with even more intensity than before. He grows increasingly sensitive to noises (74) and smells $(61,82)$, and his own sensations come to hurt him. He cannot get rid

22. See, for instance, her reaction on learning about Paul's death or the way in which she often treats her child while she is still going out with David.

23. Onega, p. 8. 
of the cold, which seems to filtrate through invisible cracks in his own body, and he notices a disgusting odour clinging to him (82), as if something were rotting inside. He feels "estranged" and "lonely" (78), and, eventually, he foresees "the down," "the dark depression" (83), which is coming on him with the inevitability of fate. He starts seeing other women again and increases his intake of drugs, but the feeling that his self is giving way, dissolving, fragmenting beyond remedy, never abandons him, until he reaches a kind of schizophrenic coma during which his mental and bodily functions seem to lead separate courses:

Something grew in him, something beyond the deep shadows that followed him as he made his way to and fro across the streets.... Often as he walked alone his legs seemed to be moving to no effect, fixed on one spot while the streets and buildings slid cumbersomely past. Something dark so that when he stopped suddenly, behind his panting he heard another gasp.

In The Culture of Narcissism, Christopher Lasch cites several psychoanalysts reporting on how their patients have been complaining of difficulties quite different from those that plagued the hysterical and obsessive compulsive patients described by Freud. ${ }^{24}$ Among these psychoanalysts, Heinz Kohut manages to capture the difference between Freud's patients and his own in his distinction between Guilty Man and Tragic Man. The guilty human is torn by drive-instinctual Oedipal conflict; the primary anxiety is, in this case, castration anxiety, and the source of this patient's guilt is incestuous and aggressive wishes. The tragic human, on the other hand, has more archaic problems (in as far as the psychic development of the individual is concerned). ${ }^{25} \mathrm{~S} /$ he cannot experience him/herself as a centre of initiative and suffers from disintegration anxiety. This patient feels despair, boredom; s/he complains of feeling empty, depressed, and, at times, unreal. In short, Tragic Man lives in fear of boundary loss, of potential fragmentation.

David's symptoms in The Sensationist are not very different from these. Moreover, they account for a picture of reality in which not only the protagonist but also everything around him - both things and people - falls apart, breaks down, and gradually dissolves into an increasingly fragmented plurality. This being so, the final section of the novel abounds in pathologised images which take us back to the dark-

24. Christopher Lasch, The Culture of Narcissism (New York: W. W. Norton, 1978), pp. 36-38.

25. These should be traced back to the dyad child/first love-object rather than to the father/mother/child triangle. 
est part of the underworld and which eventually replace the revelation phase as posited by Evans Lansing Smith. ${ }^{26}$ For modernist writers (and for their readers as well), this revelation took the form of mythical patterns, which offered them a way to cope with all the complexities and inconsistencies of the world and of man's inner reality. These mythical patterns became an image and a function of some great unity in life. Modernist characters, therefore, suffer the pains of alienation and the disquieting consequences of the loss of belief in the individual's power to take significant action and control him/herself and the world outside. As they do so, though, their afflictions get eventually healed by a view of the rainbow or the rose garden, which provides them, as it were, with the strength necessary to give the last stroke to a painting that, for a long time, they had been unable to complete.

For all its indebtedness to modernist literature, The Sensationist appears to be much bleaker than most of its predecessors in the sense that, even though the protagonist goes through the "torments" of the underworld, he misses the chance of revelation. David's intuition that Lucy is the answer to all that puzzles him comes to nothing as he never manages to overcome his fear of giving himself to another person and doing so without reservation. Lucy cannot become the centre of his life because that is already too self-centred. And yet, from another perspective, one feels that David is not the only one to blame. On the one hand, Lucy cannot save David because he does not let himself be saved, but, on the other, she cannot do such a thing because she is as much a victim as David is. She cannot become the centre of his world because hers, too, lacks a centre. What we get, then, is a sort of mise en abyme of voids within voids which extends itself from the city and its underground vacuities, to David, who uses Lucy to try and fill the void of his inner self, to Lucy herself, who, in turn, cannot fill it with anything but madness. In this light, the reader cannot help making his/hers the dreadful but inescapable conclusion reached by the protagonist, who, for all his attempts to rescue things "as if to assemble a jigsaw," ends up facing the fact that "there was no jig-saw for there was no picture" (122). And so, as the pieces cannot be put together, the only way seems to be for them to fragment even further.

The final collapse affects both work and personal life. In less than a page, the reader is offered a chaotic picture of David's workplace - now full of people shouting, phones ringing and screens going blank (129) - which is immediately followed by a nearly surrealistic scene in which David reaches Lucy's flat just in time to see her hitting Sally dead. Lacking all capacity for emotion and moral involvement, David is

26. Smith, pp. 137-138. 
initially shocked by what is going on in front of his eyes but in no way affected by it. David's mental degeneration is thus shown to be paralleled by an increasing moral degradation, which also accounts for the protagonist turning his back on the maddened Lucy in much the same way as John Huffam does with Henrietta at the end of The Quincunx. The novel ends with a depressing image of Lucy in a mental asylum and David's short visit to the place just before he takes a plane away from the city. The protagonist, then, moves off the stage as he had entered it: a formless, contentless, almost featureless self who feels nothing and has no ethical dilemmas to confront.

On the whole, Palliser's second novel portrays a tragic world in which, paradoxically, nothing looks tragic. The degeneration of the environment, David's mental split, Sally's death, Lucy's madness, they all lack the distinctive tragic quality which, as Susana Onega explains, could have conferred on them a heroic and cathartic significance. ${ }^{27}$ Accordingly, David remains indifferent to a reality (both exter$\mathrm{nal} / \mathrm{physical}$ and internal/mental) in which everything is falling to pieces, as if that were, like the business crash, a "system failure" for which nobody is to blame (70, 85). At this point, some lines by T. S. Eliot come to mind:

There are three conditions which often look alike

Yet differ completely, flourish in the same hedgerow:

Attachment to self and to things and to persons, detachment

From self and from things and from persons; and, growing

between them, indifference

Which resembles the others as death resembles life.

(“Little Gidding," Part III) ${ }^{28}$

If the medieval hell consists in the agony of perpetually remaining the self you once chose and lived, the modern hell (and Eliot's version is just one among others) lies in the incapability of ever attaining an identity - even an evil one. In a paradoxical way, as Eliot suggests above, it is better to do evil than nothing at all, because doing evil can at least be regarded as a proof that we are alive. What governs The Sensationist is precisely this something between attachment and detachment, neither good nor evil. Thus, the novel's world emerges as disquietingly inhuman and, worst of all, with no apparent possibility of change.

27. Onega, p. 11.

28. T. S. Eliot, "Little Gidding," in The Norton Anthology of English Literature, $5^{\text {th }}$ edition, Vol. 2 (New York and London: W. W. Norton \& Company, 1962), p. 2203. 
When writing The Sensationist, Palliser chose to portray the main character's subjectivity as a modernist author would have done. Yet there is a temporal breach that separates this novel from the modernist movement, a temporal breach in which - it could not have been otherwise - ideological changes have taken place and literary writers have found ways to express the new worldview by having recourse to already existing forms. It cannot be denied that The Sensationist echoes the typically modernist questioning of coherent and unitary selfhood. In the same line, it exploits the equally modernist themes of anxiety and alienation. However, it also portrays the change in what Fredric Jameson calls the dynamics of cultural pathology, namely, the progressive shift from (modernist) alienation to the (postmodernist) fragmentation of the subject.29 And just as, at the level of contents, the sequence raperevelation is truncated, split in the middle, as if the rifts affecting the protagonist's self could but get wider since they cannot be healed, so the novel's form can be said to illustrate an evolution which has left the once coherent ego further and further behind, as corresponds to the last stage of a process which has gone from wholeness to alienation and then to fragmentation, that is to say, from unity to disintegration.

Palliser creates an external narrative instance whose knowledge is always restricted to the main character's eyes and mind, as if stretching to the limit the possibilities implicit in what Henry James called "reflector" or "centre of consciousness." 30 This heterodiegetic narration is now and then interrupted by short italicised paragraphs where some of the events already described or altogether skipped over by the external narrator are reported or commented on by David himself, a David that looks back at that period of his life from some point in time posterior to the events recounted. But as important as the logic that seems to govern the relationship between typeface and narrative voice - roman-type sections-heterodiegetic narrator / italicised paragraphs-autodiegetic narrator - are the occasions when the pattern is broken: the third person is sometimes used in the sections in italics.

It is half way through the novel that we come across the first disruption: "When she arrived he sensed her mood. She took off her headscarf and shook her head.... He saw the aggression" (76-77, italics in the original). Significantly enough, this passage is closely followed by the one in which David's first schizophrenic experience is described: the protagonist slips away from where he is and contemplates himself and Lucy from a distance, as if he were remembering the episode from some time in

29. Fredric Jameson, "Postmodernism, or the Cultural Logic of Late Capitalism," New Left Review 146 (1984) 53-92, p. 63.

30. Henry James, The Art of the Novel (Boston: Northeastern UP, 1984), p. 300. 
the future (77). Given the fact that the protagonist's psychological evolution goes through stages which could be regarded as more and more clearly schizophrenic, it would not be farfetched to approach the instability that affects the grammatical persons in the text from the perspective provided by Lacan's account of schizophrenia as a disruption in the signifying chain. If, as Catherine Belsey points out (echoing Benveniste's approach), the basis of subjectivity is to be found in the exercise of language,$^{31}$ that is, if language is the only objective testimony to the identity of the subject, the linguistic strategies used in the novel may be seen as the ultimate vehicle for portraying a subject that has become nothing but a fragmented, crumbling, nearly lost object. In line with this, an analysis such as F. K. Stanzel's, which focuses on the alternation between first- and third-person pronominal reference, particularly in relation to the modern novel, 32 gains an additional topical interest from the connection that can be established between the variation in pronominal reference, on the one hand, and the psychology of the split personality, while on the other:

Psychologically speaking, ego awareness and the splitting of personality are problematic not only in pathology. The change from first- to third-person and vice versa can be found in the language of the child, especially in the development phase of "Vorichlichkeit," the state of mind of a child when it is not yet conscious of itself as individual, but also in the socially or psychologically motivated role-playing of adults. The alternation of first- and third-person references of a patient to himself is a symptom of multiple personality in adults. Thus, it is highly probable that ... the increase in the frequency of changes in pronominal reference in the modern novel is an expression of the growing identity problem of modern man. 33

The blurring of boundaries between external and internal narration effected through the use of third-person pronouns in italicised paragraphs can be seen as a reflection en abyme of the alternation throughout the novel of external and internal

31. Catherine Belsey, Critical Practice (London and New York: Routledge, 1980), p. 59.

32. Stanzel calls attention to the increasing frequency with which this alternation of pronominal reference has appeared in the novels of the most diverse modern authors. He illustrates his point with a list of works which includes Joseph Conrad's Under Western Eyes; Robert Penn Warren's All the King's Men; Saul Bellow's Herzog; Margaret Drabble's The Waterfall; Kurt Vonnegut's A Breakfast of Champions; Günter Grass's The Tin Drum; Max Frisch's Montauk; etc. F. K. Stanzel, A Theory of Narrative, trans. Charlotte Goedsche (Cambridge: Cambridge University Press, 1987), pp. 104-105.

33. Stanzel, p. 106. 
narrative voices. If we apply what refers to the italicised sections to the novel as a whole, a hypothesis takes form according to which the two narrative instances may correspond to the same narrating subject. That is to say, it can be argued there is only one (albeit fragmented) narrator in the novel, even though the subjects of narration (the pronominal references in the text) are different. This difference would mark, then, a split within a single narrating agency - rather than a distinction between two separate [narrating] agents - related to the outward and inward facets of David's fragmented self. Such a view would posit a narrating self that resists total identification with his earlier, experiencing self, and that, consequently, refers to the latter as "he."

Setting up an image of oneself and dealing with it as something external to, independent from the very self which originates it, throws the subject further and further back into fragmentation and indeterminacy, this image working, so to put it, in a direction opposite to that of the fixed imago in the mirror phase of Lacanian psychoanalysis. By narrating himself in the third person, the narrating subject of Palliser's novel questions the stability of what could be taken as a sign of his determinate, symbolic self - the first-person pronoun, that is, the capacity of articulating himself as "I" - and replaces it with the kind of disintegration that is to be found everywhere else in the novel. 34 Accordingly, The Sensationist portrays a subject caught in a game with his own image, stuck in a process in which image and source, the self as mirrored and the self as origin, can never be made to coincide, an assertion that may recall the morals of Narcissus' myth. His fate serves as a warning that the gap of reflection cannot be closed or, if closed, closed only by death; a unified consciousness is, at best, an illusion and, at worst, a drowning pool.

My analysis of Palliser's second novel began with Persephone, but by the end of it, Persephone seems to have metamorphosed into Narcissus, an interesting transformation if one looks at it in the light of the social and cultural changes that took place throughout the twentieth century. Thus, Gilles Lipovetsky has approached these changes as a development to what he calls "lère du vide." 35 To him, the second half of the century brought with it an intensification of the process of personalisation, a cult of individualism that makes of Narcissus the epitome of fin-de-siècle attitudes. Postmodern culture is decentralised, eclectic: materialism and psychology,

34. In the city's ground and buildings, in its inhabitants, in human relations (man/woman, mother/child), in the business world (the stock market, David's scheme, his work place), etc.

35. Gilles Lipovetsky, La era del vacío: Ensayos sobre el individualismo contemporáneo, trans. Jean Vinyoli and Michèle Pendanx (1983; Barcelona: Anagrama: 1988). 
pornography and discretion, innovation and nostalgia, sophistication and spontaneity, consumerism and ecology, almost everything can co-exist without contradiction. The possibilities of choice diversify and stable references and meanings are done away with. However, one key value remains: the individual and his/her right to selffulfilment. Ours is a narcissistic culture which glorifies all that has to do with the sphere of the private. As beliefs and institutions turn flexible, unsteady, the individual also aspires to become kinetic. This would explain his/her wish to "fly," to feel more, to vibrate with immediate sensations, to plunge into a sort of integral movement, as if on a never-ending sensorial or pulsional trip. As Lipovetsky concludes, the individual had never before done so many things, accumulated so much material wealth and been so tormented by a feeling of emptiness. The void is also at the core of the modern metropolis, a paradoxical desert, without catastrophe, without tragedy or vertigo, in which the individual falls prey to a generalised disenchantment, a diffused malaise that invades all.

This Narcissus subjugated in his bell jar that emerges as a typical product of the second half of the twentieth century, this individual that lives in flash-sequence always wanting to do more, feel more, but also unable to commit, and so, unable to find an external centre of gravity that can hold the self together, and with the self, his/her wishes, impulses, inclinations - is also "the sensationist" of Palliser's novel, a work that can thus be said to provide a disheartening though precise view of this socalled Narcissistic culture in the age of the void. 